\title{
Canonical Correlation Analysis Between Growth and Nutrition in Teak Seedlings
}

\author{
Cristiane Ramos Vieira ${ }^{1}$ (D), Oscarlina Lúcia dos Santos Weber ${ }^{2}$ (D), Kuang \\ Hongyu $^{3}$ (D), José Fernando Scaramuzza² \\ ${ }^{1}$ Faculdade de Agronomia, Universidade de Cuiabá - UNIC, campus Beira Rio I, Cuiabá - MT, Brasil \\ ${ }^{2}$ Faculdade de Agronomia e Zootecnia, Universidade Federal de Mato Grosso - UFMT, Cuiabá - MT, Brasil \\ ${ }^{3}$ Departamento de Estatística, Universidade Federal de Mato Grosso - UFMT, Cuiabá - MT, Brasil
}

\begin{abstract}
The relationship between nutrients and plant growth requires in-depth studies and the application of statistical analysis capable of explaining these interactions. An experiment was prepared with N, $\mathrm{P} 2 \mathrm{O} 5$ and $\mathrm{K} 2 \mathrm{O}$ doses. Effects on the correlations between growth and nutrients in Tectona grandis seedlings were based on the canonical correlation analysis. Seedlings were submitted to doses of $\mathrm{N}=0,2.5,5.0,7.5 \mathrm{~kg} \mathrm{~m}^{-3}$ with urea, $\mathrm{P} 2 \mathrm{O} 5=0,3.0,6.0,12.0 \mathrm{~kg} \mathrm{~m}^{-3}$ with common superphosphate, and $\mathrm{K} 2 \mathrm{O}=0,3.0,6.0,12.0 \mathrm{~kg} \mathrm{~m}^{-3}$ with potassium chloride, in a completely randomized design. Canonical correlations showed that biomass was the most salient morphological characteristic in relation to the growth of $T$. grandis seedlings. Height and diameter were also underscored by interactions between macro- and micronutrients in the substrate, after fertilization. Results show that $\mathrm{N}, \mathrm{Mn}$ and $\mathrm{Cu}$ were the most important nutrients for the increment of these characteristics.
\end{abstract}

Keywords: Tectona grandis, multivariate analysis, fertilization, seedling production.

\section{Análise de Correlação Canônica entre Crescimento e Nutrição em Mudas de Teca}

\begin{abstract}
RESUMO
Determinar a relação existente entre os nutrientes e o crescimento das plantas implica em estudos e a aplicação de análise estatística capaz de explicar essas interações. Diante disso, estabeleceu-se experimento com doses de $\mathrm{N}, \mathrm{P}_{2} \mathrm{O}_{5}$ e $\mathrm{K}_{2} \mathrm{O}$ e seus efeitos nas correlações entre crescimento e os nutrientes em mudas de Tectona grandis, a partir da correlação canônica. As mudas foram submetidas às doses de $\mathrm{N}=0,2,5,5,0$ e 7,5 $\mathrm{kg} \mathrm{m}^{-3}$ com ureia, $\mathrm{P}_{2} \mathrm{O}_{5}=0,3,0,6,0$ e 12,0 $\mathrm{kg} \mathrm{m}^{-3}$ com superfosfato simples e $\mathrm{K}_{2} \mathrm{O}=0$, 3,0, 6,0 e 12,0 $\mathrm{kg} \mathrm{m}^{-3}$ com cloreto de potássio, em delineamento inteiramente casualizado. As correlações canônicas demonstraram que a biomassa foi a característica morfológica que mais se destacou em relação ao crescimento das mudas de T. grandis. Essa característica, assim como altura e diâmetro, foi favorecida pelas interações entre os macro e micronutrientes, que ocorreram no substrato após a adubação. $\mathrm{N}, \mathrm{Mn}$ e $\mathrm{Cu}$ foram os nutrientes mais importantes para o incremento dessas características.
\end{abstract}

Palavras-chave: Tectona grandis, análise multivariada, adubação, produção de mudas. 


\section{INTRODUCTION}

Teak (Tectona grandis L. f.) is a species of the Verbenaceae family, native to the Indian subcontinent and southeastern Asia. It is one of the most cultivated trees in Brazil during the last decades, with 87,499 hectares in 2014 (IBÁ, 2016). Its wood is highly appreciated for its excellent quality (Bonduelle et al., 2015) and has been largely employed in boat building, fine furniture, frames, panels, veneers and carvings (Coimbra et al., 2014). Favare et al. (2012) reported that, after the application of lime, its nutritional features follow the sequence: $\mathrm{N}>\mathrm{Ca}>\mathrm{K}>\mathrm{Mg}>\mathrm{P}>\mathrm{S}>\mathrm{Fe}>\mathrm{Mn}>\mathrm{B}>\mathrm{Zn}>\mathrm{Cu}$. However, few research works have been undertaken to study the species' growth and nutrition status in greenhouses after fertilization with $\mathrm{N}, \mathrm{P}$ and $\mathrm{K}$.

$\mathrm{N}, \mathrm{P}$ and $\mathrm{K}$ are commonly used for soil fertilization in the production of seedlings in greenhouses (Dias et al., 2015; Menegatti et al., 2017). For the composition of the fertilizers, sources may contain small quantities of micronutrients along with macronutrients. Depending on the amount already in the soil, it may or may not be sufficient to maintain the growth of the seedlings till the planting phase.

Greenhouses use mineral fertilizers to enhance growth in plants, especially when substrates do not have the required nutrient concentration, as in native soil used as a substrate. Fertilization should have the required amounts of nutrients for growth (Gonçalves et al., 2014; Cardoso et al., 2016) and should not enhance negative interactions in the soil. Otherwise, plants growth would be curbed. The plants' morphological characteristics and the manner nutrients affect them should be investigated.

Canonical co-relationship has thus been employed. According to Hair et al. (2009), canonical co-relationship investigates simultaneously multiple dependent variables as from multiple independent ones. It comprises co-relationships between canonical variables, or rather, between linear combinations of variables, so that the correlation among these combinations is highest. Consequently, no other linear combination of variables will be higher than this combination (Trugilho et al., 2003). Co-relationships will be an asset in analyzing the manner morphological characteristics are affected by nutrients and, consequently, how they affect seedlings growth.

Since it is important to establish the manner nutrients influence the seedlings' morphological characteristics and their growth, an experiment with $\mathrm{N}, \mathrm{P}_{2} \mathrm{O}_{5}$ and $\mathrm{K}_{2} \mathrm{O}$ doses was performed to evaluate their effects on the correlation between nutrients and the growth of T. grandis seedlings, by canonical co-relationship.

\section{MATERIAL AND METHODS}

The experiment was performed in a greenhouse built of shade-screen on the sides and covered with asbestos tiles, without any temperature control, at the Faculty of Agronomy, Veterinary Medicine and Animal Science of the Universidade Federal de Mato Grosso, Brazil. The greenhouse was chosen for protection during the experiment and for greater data reliability.

Seedlings were produced by seeds. Dormancy was broken in flowing water, during 24 hours. Seeds were sown in small $54 \mathrm{~cm}^{3}$ tubes filled with commercial substrate (80\%) and vermiculite (20\%). First germinations were detected ten days after seeding, followed by thinning. Seedlings reached a height of $15 \mathrm{~cm}$ after 20 days and were ready for transplanting.

Soil was classified as dystrophic red latosol, with sandy texture, retrieved from the native savannah area in the Instituto Federal de Mato Grosso, campus São Vicente da Serra. Soil sample was dried in the open, sieved by a $2 \mathrm{~mm}$ net and analyzed for its chemical properties, following method by Embrapa (1997), given in Table 1.

Table 1 shows that soil saturation was base increased to $50 \%$, with $1.53 \mathrm{t} \mathrm{ha}^{-1}$ lime, PRNT $100 \%$, with $30 \%$

Table 1. Chemical analysis of soil.

\begin{tabular}{|c|c|c|c|c|c|c|c|c|c|c|c|c|}
\hline pH & $\mathbf{K}$ & $\mathbf{P}$ & $\mathbf{H}+\mathbf{A l}$ & Al & $\mathrm{Ca}$ & $\mathrm{Mg}$ & SB & $\mathbf{T}$ & $\mathbf{T}$ & $\mathbf{V}$ & m & MO \\
\hline $\mathrm{CaCl}_{2}$ & & & \multicolumn{7}{|c|}{$\mathrm{cmol}_{\mathrm{c}} \mathrm{dm}^{-3}$} & \multicolumn{2}{|c|}{$\%$} & $\mathrm{~g} \mathrm{~kg}^{-1}$ \\
\hline 4.39 & 13.56 & 13.90 & 4.22 & 1.03 & 1.0 & 0.50 & 1.53 & 5.75 & 2.56 & 26.5 & 40.2 & 22 \\
\hline
\end{tabular}

$\mathrm{pH}$ in $\mathrm{CaCl}_{2}$ - ratio 1:2.5; $\mathrm{H}+\mathrm{Al}$ - in calcium acetate; $\mathrm{Al}, \mathrm{Ca}$ and $\mathrm{Mg}$ - in $\mathrm{KCl} 1 \mathrm{~N} ; \mathrm{P}$ and $\mathrm{K}$ - in Mehlich; $\mathrm{SB}$ - sum of bases; $\mathrm{T}$ - capacity for ion exchange at $\mathrm{pH} 7.0 ; \mathrm{t}$ - true CTC; $\mathrm{V} \%$ - saturation by bases in \%; $\mathrm{m} \%$ - saturation by $\mathrm{Al}$ in \%; MO - Organic Matter, burnt in oven. 
$\mathrm{CaO}$ and 21\% MgO, with 15 days for incubation. Limed soil was employed to fill $50 \mathrm{~cm}$ (height) $\times 40 \mathrm{~cm}$ (circumference) plastic bags, with a volume of $62,800 \mathrm{~cm}^{3}$. Seedlings were transplanted to the bags and remained there throughout the experiment.

After transplant, $\mathrm{N}, \mathrm{P}_{2} \mathrm{O}_{5}$ and $\mathrm{K}_{2} \mathrm{O}$ doses were applied and used as treatments: $0 ; 2.5 ; 5.0 ; 7.5 \mathrm{~kg} \mathrm{~m}^{-3} \mathrm{~N}$, with urea; $0 ; 3.0 ; 6.0 ; 12.0 \mathrm{~kg} \mathrm{~m}^{-3} \mathrm{P}_{2} \mathrm{O}_{5}$, with common superphosphate; $0.0 ; 3.0 ; 6.0 ; 12.0 \mathrm{~kg} \mathrm{~m}^{-3} \mathrm{~K}_{2} \mathrm{O}$, with potassium chloride. No other micronutrients were added. Doses were applied once, directly in the soil, at the seedlings' base, at a depth of approximately $2 \mathrm{~cm}$. Design was totally randomized with factorial scheme $4 \times 4 \times 4$ and 12 replications.

Fertilizer sources were the same as those used for T. grandis, and doses were those employed in research work on the same theme. After 15 days of transplant and fertilization of substrate, the growth process was monitored.

Height and diameter were evaluated on the $60^{\text {th }}$ day. Height was measured by a ruler from the soil surface to the apical bud, whilst collar diameter was measured by digital caliper. Seedlings were divided into leaves, stalk and root to measure biomass features. Roots were washed in flowing water; all vegetal material was dried in an air buffer at $65^{\circ} \mathrm{C}$ till constant weight. They were weighed on a semi-analytic scale, at $0.05 \mathrm{~g}$ precision. Leaf dry matter was ground and underwent macro- and micronutrient analysis following method by Malavolta et al. (1997).

\subsection{Canonical Correlation Analysis - CCA}

CCA was based on original data of each morphological characteristic to verify the associations between growth and macronutrients, between growth and micronutrients, and between macro- and micronutrients. The five morphological characteristics were represented by dependent variables $(\mathrm{X})$, whilst the six macronutrients were represented by independent variables $(\mathrm{Y})$, with three canonical functions. The same occurred for correlations between morphology (X) and micronutrients (Y) and for macronutrients $(\mathrm{X})$ and micronutrients $(\mathrm{Y})$.

Correlations between original variables and their canonical variables and crossed canonical loads were determined to represent the correlation between the group's original variable and the canonical statistical variable of the other. First step comprised multi-collinearity between the variables. Variance inflation factor (VIFj) was calculated by Equation 1:

$V I F_{j}=\frac{1}{1-R_{j}^{2}}$

where $R_{j}^{2}$ is the coefficient of determination of $x_{j}$ in the variables. $V I F_{j}>10$ is a crucial value in the calculation of regression coefficients. Variables with such rates should be analyzed and removed (Draper \& Smith, 1998; Kutner et al., 2004).

Table 2 shows that data do not have multi-collinearity, since all variables feature $V I F_{j}<10$. Likelihood ratio test, whose statistics is called Wilks' Lambda (L), was employed to verify canonical correlation significance for canonical

Table 2. Inflation variance factor by variable.

\begin{tabular}{|c|c|c|c|c|c|c|}
\hline \multicolumn{7}{|c|}{ Growth and macronutrient correlation } \\
\hline Variable & Height & Diameter & Bio leaf & Bio stalk & Bio root & -- \\
\hline VIF & 1.6315 & 1.6444 & 1.4114 & 2.5382 & 1.6672 & -- \\
\hline Variable & $\mathbf{N}$ & $\mathbf{P}$ & $\mathbf{K}$ & $\mathrm{Ca}$ & $\mathrm{Mg}$ & $\mathbf{S}$ \\
\hline VIF & 1.4019 & 1.2217 & 1.2037 & 1.1774 & 1.2548 & 1.1579 \\
\hline \multicolumn{7}{|c|}{ Growth and micronutrient correlation } \\
\hline Variable & Height & Diameter & Bio leaf & Bio stalk & Bio root & -- \\
\hline VIF & 1.6512 & 1.6353 & 1.4063 & 2.5609 & 1.6949 & -- \\
\hline Variable & $\mathrm{Cu}$ & Fe & Mn & $\mathrm{Zn}$ & B & -- \\
\hline VIF & 1.0987 & 1.0452 & 1.2939 & 1.2922 & 1.0643 & -- \\
\hline \multicolumn{7}{|c|}{ Macronutrients and micronutrients correlation } \\
\hline Variable & $\mathbf{N}$ & $\mathbf{P}$ & $\mathbf{K}$ & $\mathrm{Ca}$ & Mg & S \\
\hline VIF & 1.3892 & 1.2641 & 1.3298 & 1.1797 & 1.3344 & 1.1497 \\
\hline Variable & $\mathrm{Cu}$ & $\mathrm{Fe}$ & Mn & $\mathrm{Zn}$ & B & -- \\
\hline VIF & 1.0905 & 1.0563 & 1.3061 & 1.4319 & 1.0891 & -- \\
\hline
\end{tabular}


pairs. Test was undertaken with SAS CONCORR procedure, with equations by Khattree \& Naik (2000).

The amount of variance, or rather, variance percentage in the dependent canonical statistical variable that may be explained by the independent canonical statistical variable and vice-versa, was calculated by squaring canonical correlation (canonical $\mathrm{R}^{2}$ ). The amount of shared variance between the dependent and independent variables observed and their respective canonical statistical variables was determined by squaring the canonical loads, following Protásio et al. (2012).

CCA may be the generalization of a multiple linear regression for more than one dependent variable, even though it does not differentiate dependent variables from independent ones by simply analyzing two variable groups. CCA summarizes data in the two sets of variables in two linear combinations that maximize the correlation between the two groups called statistical canonical variables (Mingoti, 2005). Therefore, canonical correlations are the correlation coefficients between the two statistical canonical variables.

Let $\boldsymbol{X}^{\prime}=\left[x_{1}, x_{2}, \ldots, x_{p}\right]$ and $\boldsymbol{Y}^{\prime}=\left[y_{1}, y_{2}, \ldots, y_{q}\right]$ be the vectors of the characteristics of the two groups of variables, I and II, respectively. Coefficient estimates of linear combinations of the two groups to estimate maximum correlation between the combinations.
If $X_{1}$ and $Y_{1}$ are the first combinations of the group of variables I and II respectively, then de Equations 2 and 3:

$X_{1}=a_{1} x_{1}+a_{2} x_{2}+\ldots+a_{p} x_{p}$

and

$Y_{1}=b_{1} y_{1}+b_{2} y_{2}+\ldots+b_{q} y_{q}$

where $\boldsymbol{a}^{\prime}=\left[a_{1}, a_{2}, \ldots, a_{p}\right]$ is the vector $1 \times \mathrm{p}$ of weights of the characteristics of group I and $\mathbf{b}{ }^{\prime}=\left[b_{1}, b_{2}, \ldots, b_{q}\right]$ is the vector $1 \times q$ of weights of the characteristics of group II (Johnson \& Wichern, 2007). In current study, CCAs were performed with statistical program R Development Core Team (2014).

\section{RESULTS AND DISCUSSION}

\subsection{Growth and macronutrients}

Table 3 gives canonical correlations for growth and macronutrients for the three most important correlations. However, the first two already account for $82.6 \%$ of data variation. They may explain seedling growth of $T$. grandis with regard to macronutrients available in the substrate after N, P and K fertilization.

Since the greater the canonical load, the more important is the variable for the characteristic to be accounted for (Hair et al., 2005), the stalk biomass was the most important morphological characteristic, as

Table 3. Canonical correlations, canonical $\mathrm{R}^{2}$ and percentage to account for correlation between growth and macronutrient, growth and micronutrients, macronutrients and micronutrients.

\begin{tabular}{|c|c|c|c|c|c|c|}
\hline \multicolumn{7}{|c|}{ Growth and macronutrients } \\
\hline $\begin{array}{l}\text { Canonical } \\
\text { function }\end{array}$ & $\begin{array}{l}\text { Canonical } \\
\text { correlation }\end{array}$ & $\mathbf{R}^{2}$ & Percentage & $\begin{array}{l}\text { Accumulated } \\
\text { percentage }\end{array}$ & Wilks' & p-value \\
\hline 1 & 0.4192 & 0.2132 & 61.78 & 61.78 & 0.7251 & 0.0011 \\
\hline 2 & 0.2591 & 0.0720 & 20.86 & 82.64 & 0.8797 & 0.2552 \\
\hline 3 & 0.1013 & 0.0493 & 14.28 & 96.92 & 0.9430 & 0.5414 \\
\hline \multicolumn{7}{|c|}{ Growth and micronutrients } \\
\hline $\begin{array}{l}\text { Canonical } \\
\text { function }\end{array}$ & $\begin{array}{l}\text { Canonical } \\
\text { correlation }\end{array}$ & $\mathbf{R}^{2}$ & Percentage & $\begin{array}{l}\text { Accumulated } \\
\text { percentage }\end{array}$ & Wilks' & p-value \\
\hline 1 & 0.3606 & 0.1494 & 48.53 & 48.53 & 0.7471 & 0.0006 \\
\hline 2 & 0.3099 & 0.1062 & 34.49 & 83.02 & 0.8587 & 0.0295 \\
\hline 3 & 0.2040 & 0.0434 & 14.10 & 97.12 & 0.9499 & 0.3903 \\
\hline \multicolumn{7}{|c|}{ Macronutrients and micronutrients } \\
\hline $\begin{array}{l}\text { Canonical } \\
\text { function }\end{array}$ & $\begin{array}{l}\text { Canonical } \\
\text { correlation }\end{array}$ & $\mathbf{R}^{2}$ & Percentage & $\begin{array}{l}\text { Accumulated } \\
\text { percentage }\end{array}$ & Wilks' & p-value \\
\hline 1 & 0.4822 & 0.3029 & 58.41 & 58.41 & 0.6249 & 0.0000 \\
\hline 2 & 0.3452 & 0.1353 & 26.09 & 84.50 & 0.8142 & 0.0088 \\
\hline 3 & 0.2348 & 0.0584 & 11.25 & 95.75 & 0.9244 & 0.2673 \\
\hline
\end{tabular}


canonical function 1 demonstrates (Table 4). It was actually the most relevant characteristic in the growth of T. grandis seedlings. According to canonical correlation I, the other variables ranking next were root biomass, leaf biomass, height and diameter.

Leaf, stalk and root biomass were the most relevant morphological characteristics during the growth of T. grandis seedling, as canonical function I demonstrates. In fact, growth occurred adequately since height and diameter increase followed biomass growth. This boils down to the fact that the substrate made available the amount of nutrients required by the species. It also provided physical conditions for the development of the plant's root system.

Stalk biomass increase was important to bear the plant size and, simultaneously, enhanced the diameter growth of the seedlings. In fact, root biomass was relevant for the plant's total development: its nutrition improved when it absorbed the nutrients, especially those (P and $\mathrm{K}$ ) with low mobility in the soil, enhanced by fertilization.

$\mathrm{N}$ was the most underscored macronutrient. Other variables were $\mathrm{S}, \mathrm{P}, \mathrm{K}, \mathrm{Mg}$ and $\mathrm{Ca}$, in order of importance. The relevance of $\mathrm{N}$ for the growth of $T$. grandis seedlings has been reported by Favare et al. (2012) and Trazzi et al. (2014). According to Gonçalves et al. (2012), as a general rule, plants need large amounts of $\mathrm{N}$, especially during the development phase. The above further foregrounds the seedlings total growth since $\mathrm{N}$ is related to this specific characteristic of the plant.
Barroso et al. (2005) reported that, when $\mathrm{N}$ was lacking in T. grandis seedlings, a severe growth decrease, general chlorosis, non-emission of new roots and rotting of secondary roots occurred. According to these authors, the lack of macronutrients jeopardized the initial development of species seedlings. However, the absence of $\mathrm{N}$ and Ca caused immediate and more intense damages.

Root biomass, followed by height, leaf biomass, diameter and biomass of the stalk are underscored by canonical function II (Table 4) of the correlation between growth and macronutrients. The above was highly relevant for the growth of T. grandis seedlings and the production of stalk and leaf biomass, underscored in function I.

Height and leaf biomass directly correlated with all macronutrients. According to Lange et al. (2014), height is a good index of seedling quality, even though the tallest seedling is the best. A greater height which is not coupled to the collar's diameter growth frequently denotes blanching and the need for proportional growth. The production of the seedlings biomass should also be investigated, reinforcing the fact that the growth of T. grandis seedlings has occurred adequately.

Root biomass is related to $\mathrm{P}$, the most important variable for macronutrients, according to canonical function II. The other underscored variables were $\mathrm{K}$, $\mathrm{Ca}, \mathrm{N}, \mathrm{S}$ and Mg. Carnevali et al. (2016) reported that $\mathrm{P}$ was the main nutrient to trigger biomass accumulation in seedlings of Stryphnodendron polyphyllum. The above

Table 4. Canonical loads and cross canonical loads for canonical functions I and II in the growth and macronutrient correlation.

\begin{tabular}{|c|c|c|c|c|}
\hline \multirow[b]{2}{*}{ Variables } & \multicolumn{2}{|c|}{ Canonical function I } & \multicolumn{2}{|c|}{ Canonical function II } \\
\hline & Canonical loads & $\begin{array}{c}\text { Cross canonical } \\
\text { loads }\end{array}$ & Canonical loads & $\begin{array}{c}\text { Cross canonical } \\
\text { loads }\end{array}$ \\
\hline \multicolumn{5}{|c|}{ Morphological characteristics } \\
\hline Height & 0.5562 & 0.2331 & -0.3993 & -0.1035 \\
\hline Diameter & 0.1015 & 0.0425 & 0.2263 & 0.0586 \\
\hline Leaf biomass & 0.6398 & 0.2682 & -0.2573 & -0.0667 \\
\hline Stalk biomass & 0.8285 & 0.3473 & 0.1821 & 0.0472 \\
\hline Root biomass & 0.6945 & 0.2911 & 0.6141 & 0.1591 \\
\hline \multicolumn{5}{|c|}{ Macronutrients } \\
\hline $\mathrm{N}$ & -0.8959 & -0.3755 & -0.3307 & -0.0857 \\
\hline $\mathrm{P}$ & 0.3377 & 0.1416 & -0.7728 & -0.2003 \\
\hline $\mathrm{K}$ & -0.3154 & -0.1322 & -0.5304 & -0.1374 \\
\hline $\mathrm{Ca}$ & 0.0023 & 0.0009 & -0.3493 & -0.0905 \\
\hline $\mathrm{Mg}$ & 0.3152 & 0.1321 & -0.1745 & -0.0452 \\
\hline $\mathrm{S}$ & 0.4774 & 0.2001 & -0.1836 & -0.0476 \\
\hline
\end{tabular}


denotes its importance in the initial growth stages, attributed to its functions in plants. Barroso et al. (2005) insisted that $T$. grandis seedlings without P triggered wrinkling at the edges of older leaves and mild chlorosis.

Growth impairment and deficiency symptoms in substrates with low $\mathrm{P}$ rates are due to the fact that $\mathrm{P}$ is related to photosynthesis processes, respiration, cell division and growth (Malavolta et al., 1997). Further, it enhances the growth of the root system since the roots of young plants absorb phosphates faster than the roots of older plants (Gomes \& Paiva, 2006), affecting the plant's growth and the absorption of the other nutrients (Stahl et al., 2013).

Redundancy index reached $8.27 \%$ when dependent variables were morphological characteristics, accounted for by independent canonical variables (macronutrients). Dependent variable reached $5.93 \%$ of variance of independent variables (Figure 1). Protásio et al. (2012) also reported low variances and attributed results to low canonical loads among other correlated characteristics.

\subsection{Growth and micronutrients}

Table 3 shows the main canonical functions that account for growth-micronutrients correlations. Analyses were performed since macronutrient sources may also contain amounts of micronutrients, as in the case of common superphosphate used in current assay to make $\mathrm{P}$ available. Added micronutrients plus those in the soil may trigger seedling growth, interactions with macronutrients or even with other micronutrients, enhancing or not the plant's growth.
Canonical functions I and II account for $83 \%$ of data variation. Underscored morphological characteristic in canonical function I (Table 5) was root biomass, followed by stalk biomass, very similar to growth-macronutrient correlations. Other characteristics related to seedling growth, in order of relevance, were diameter, height and leaf biomass, corroborating the importance of biomass production for height and diameter increase.

Among the micronutrients, canonical function I underscored $\mathrm{Mn}$, followed by $\mathrm{B}, \mathrm{Zn}, \mathrm{Cu}$ and $\mathrm{Fe}$. Mn was the most important micronutrient for biomass increase of T. grandis seedlings. Favare et al. (2012) and Trazzi et al. (2014) also rated Mn as one of the most important micronutrients for growth of the species, making necessary its adequate concentrations.

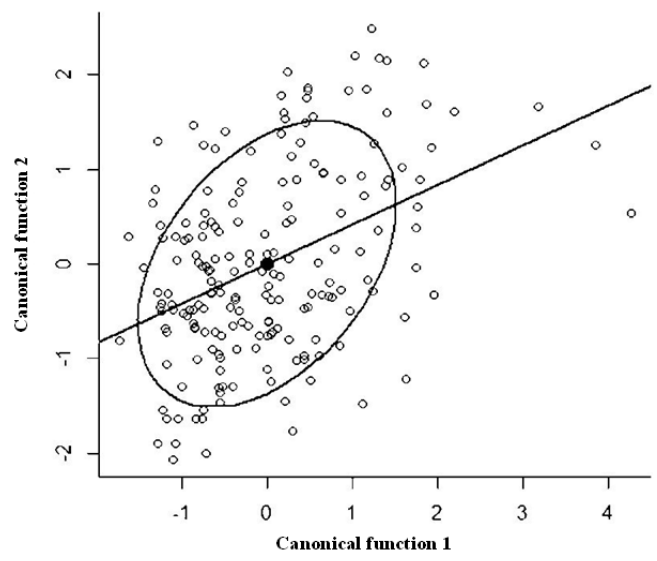

Figure 1. Standardized scores of canonical functions 1 and 2 in the growth-macronutrient correlation.

Table 5. Canonical loads and canonical cross loads for canonical functions I and II in the correlation between growth and micronutrients.

\begin{tabular}{|c|c|c|c|c|}
\hline Variables & Canonical loads & $\begin{array}{c}\text { Cross canonical } \\
\text { load }\end{array}$ & Canonical loads & $\begin{array}{c}\text { Cross canonical } \\
\text { load }\end{array}$ \\
\hline \multicolumn{5}{|c|}{ Morphological characteristics } \\
\hline Height & -0.5601 & -0.2020 & 0.7300 & 0.2262 \\
\hline Diameter & -0.6669 & -0.2405 & 0.0025 & 0.0008 \\
\hline Leaf biomass & -0.4801 & -0.1731 & 0.1743 & 0.0541 \\
\hline Stalk biomass & -0.7192 & -0.2593 & 0.3857 & 0.1195 \\
\hline Root biomass & -0.8189 & -0.2953 & -0.1202 & -0.0372 \\
\hline \multicolumn{5}{|c|}{ Micronutrients } \\
\hline $\mathrm{Cu}$ & 0.3895 & 0.1404 & -0.7182 & -0.2225 \\
\hline $\mathrm{Fe}$ & 0.1384 & 0.0499 & 0.3115 & 0.0965 \\
\hline $\mathrm{Mn}$ & 0.6592 & 0.2377 & 0.2784 & 0.0863 \\
\hline $\mathrm{Zn}$ & 0.5435 & 0.1960 & 0.6422 & 0.1990 \\
\hline $\mathrm{B}$ & 0.5694 & 0.2037 & -0.1947 & -0.0603 \\
\hline
\end{tabular}


In canonical function II, height was the most relevant morphological characteristic and demonstrated that micronutrients, mainly $\mathrm{Fe}, \mathrm{Mn}$ and $\mathrm{Zn}$, are directly related to this characteristic. Results were corroborated by Favare et al. (2012) and Trazzi et al. (2014).

$\mathrm{Cu}$ was the most important micronutrient in canonical function II since its availability was enhanced by fertilization. In this case, $\mathrm{Cu}$ and $\mathrm{B}$ were directly related to root biomass, whilst Fe, $\mathrm{Mn}$ and $\mathrm{Zn}$ were related to height, diameter, leaf and stalk biomass.

Although Favare et al. (2012) and Trazzi et al. (2014) pinpointed $\mathrm{Cu}$ as one of the less absorbed micronutrients by $T$. grandis seedlings, in current assay, $\mathrm{Cu}$ rates may have been increased by fertilization. In fact, there is a great relationship between $\mathrm{N}$ and $\mathrm{Cu}$, enhancing plant growth (Malavolta, 1980).

In the case of relationship between morphology and micronutrients, redundancy index reached $7.67 \%$ for dependent variables, accounting for $6.09 \%$ of variance of independent variables (Figure 2).

\subsection{Macronutrients and micronutrients}

Macro- and micronutrients are correlated to enhance the growth of T. grandis seedlings. Table 3 gives the two main canonical functions for such correlation, accounting for $84.5 \%$ of data variation.

After the interaction between macro- and micronutrients in the substrate, $\mathrm{K}$ was salient in canonical function I and was directly correlated with $\mathrm{Fe}, \mathrm{Mn}$ and $\mathrm{Zn}$, as Table 6 shows.

$\mathrm{K}$ is one of the nutrients most related to the growth of T. grandis seedlings. According to Valeri \& Corradini (2000), potassium enhances thickening of the seedlings collar during the production phase, even reported in the assay. It is also an asset for height increase due to its functions on the plant's osmotic regulation (Malavolta et al., 1997).

Greatest canonical load in the case of micronutrients was reported for $\mathrm{Zn}$, correlated to $\mathrm{N}, \mathrm{P}, \mathrm{K}, \mathrm{Ca}, \mathrm{Mg}$ and S. In fact, its rate was enhanced by all macronutrients. Souza et al. (2012) registered that the response

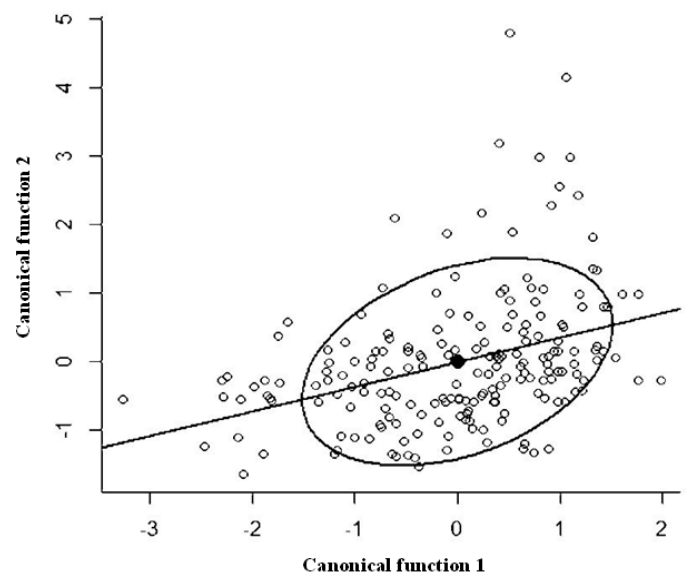

Figure 2. Standardized scores of canonical functions 1 and 2 in the growth-micronutrients correlation.

Table 6. Canonical loads and canonical cross loads for canonical functions I and II in the macronutrients and micronutrients correlation.

\begin{tabular}{ccccc} 
Variables & Canonical load & $\begin{array}{c}\text { Cross canonical } \\
\text { load }\end{array}$ & Canonical load & $\begin{array}{c}\text { Cross canonical } \\
\text { load }\end{array}$ \\
\hline $\mathrm{N}$ & 0.2138 & Macronutrients & -0.3164 \\
$\mathrm{P}$ & 0.5762 & 0.1031 & -0.9164 & 0.0685 \\
$\mathrm{~K}$ & 0.8097 & 0.2778 & 0.1984 & -0.0794 \\
$\mathrm{Ca}$ & 0.0495 & 0.3904 & -0.2301 & -0.1023 \\
\hline $\mathrm{Mg}$ & 0.2798 & 0.0239 & -0.2962 & 0.1324 \\
\hline $\mathrm{S}$ & 0.1694 & 0.1349 & 0.3835 & 0.0642 \\
\hline $\mathrm{Cu}$ & & 0.0817 & 0.1861 & -0.1208 \\
\hline $\mathrm{Fe}$ & -0.3530 & Micronutrients & & 0.1874 \\
\hline $\mathrm{Mn}$ & 0.0195 & -0.1702 & -0.3500 & -0.1935 \\
\hline $\mathrm{Zn}$ & 0.5633 & 0.0094 & 0.5428 & -0.0534 \\
\hline $\mathrm{B}$ & 0.8911 & 0.2716 & -0.5605 & -0.2237 \\
\hline
\end{tabular}


capacity of $\mathrm{Zn}$ by Peltophorum dubium was directly affected by the interaction of the other nutrients, mainly in relation to $\mathrm{N}$ and $\mathrm{P}$. Mn was another underscored micronutrient which also positively correlated with all the other macronutrients. The above accounts for its relationship with the growth of $T$. grandis seedlings.

In canonical function II (Table 6), $\mathrm{N}$ was the most relevant macronutrient for the nutrients' interaction and availability, with direct relationship with $\mathrm{Cu}, \mathrm{Mn}, \mathrm{Zn}$ and $\mathrm{B}$ in the plants. The above corroborates its importance in the production of biomass in T. grandis seedlings. Consequently, B was the most salient micronutrient with the greatest canonical load, correlating with $\mathrm{N}, \mathrm{K}$ and $\mathrm{Ca}$.

In current assay, interactions with B may have been enhanced by the fertilizers. Growth conditions of T. grandis seedlings improved due to their need for B. Locatelli et al. (2006) proved that, when B is absent in the nutrition solution applied to T. grandis seedlings, the later had their development jeopardized, with dead leaf tips, necrosis in new leaves, starting from the tips, and more pronounced nerves. According to Inocêncio \& Carvalho (2013), B's main function is cell division, more intense in the aerial segment. Further, B may be correlated with $\mathrm{Ca}$ in the formation of the cell wall to maintain plant rigidity.

Redundancy index in correlation between macro- and micronutrients reached $7.73 \%$ for dependent variables, accounting for 9.94\% of independent variables (Figure 3).

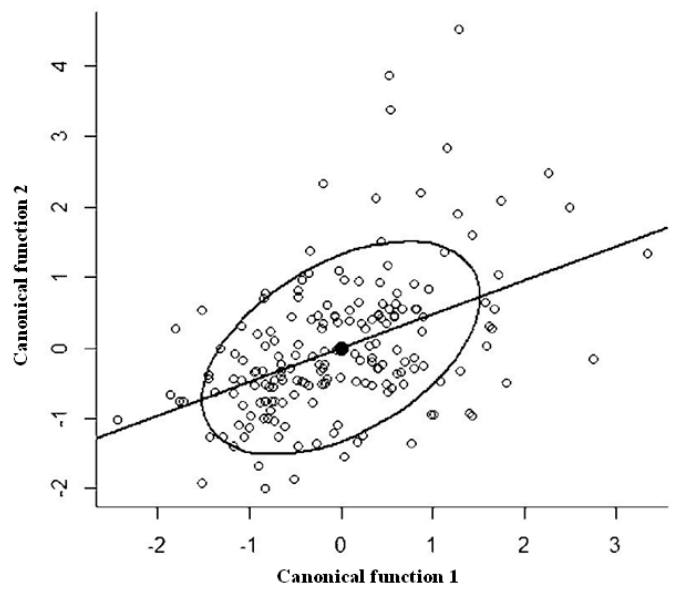

Figure 3. Standardized scores of canonical functions 1 and 2 for macronutrients and micronutrients correlation.

\section{CONCLUSIONS}

Biomass was the morphological characteristic that most contributed towards the growth of $T$. grandis seedlings produced in fertilized substrate with $\mathrm{N}, \mathrm{P}$ and $\mathrm{K}$ doses. Height and diameter were the characteristics conditioned by biomass production.

$\mathrm{N}$ was the most relevant macronutrient for the growth of T. grandis seedlings and enhanced interactions with the others. It may have also contributed towards biomass and thus in the seedling growth as a whole.

$\mathrm{Mn}$ and $\mathrm{Cu}$ were the most important micronutrients in the growth of $T$. grandis seedlings and enhanced by interactions with macronutrients.

K positively interacted with $\mathrm{Fe}, \mathrm{Mn}, \mathrm{Zn}$ and $\mathrm{Mn}$; $\mathrm{Zn}$ positively interacted with all the macronutrients, whilst B interacted with $\mathrm{N}, \mathrm{K}$ and $\mathrm{Ca}$.

\section{SUBMISSION STATUS}

Received: 30 july, 2017

Accepted: 19 feb., 2018

\section{CORRESPONDENCE TO}

\section{Cristiane Ramos Vieira}

Faculdade de Agronomia, Universidade de Cuiabá - UNIC, Campus Beira Rio I, Rua Manoel Jose de Arruda, 3100, Bairro Jardim Europa, CEP 78065-900, Cuiabá, MT, Brasil e-mail: cris00986@hotmail.com

\section{FINANCIAL SUPPORT}

Fundação de Amparo à Pesquisa de Mato Grosso (Grant/Award 751851/2011, FAPEMAT nº 009/2011).

\section{REFERENCES}

Barroso DG, Figueiredo FAMMA, Pereira RC, Mendonça AVR, Silva LC. Diagnóstico de deficiências de macronutrientes em mudas de teca. Revista Árvore 2005; 29(5): 671-679. http://dx.doi.org/10.1590/S0100-67622005000500002.

Bonduelle GM, Iwakiri S, Trianoski R, Prata JG, Rocha VY. Análise da massa específica e da retrabilidade da madeira de Tectona grandis nos sentidos axial e radial do tronco. Floresta 2015; 45(4): 671-680. http://dx.doi.org/10.5380/ rf.v45i4.31991. 
Cardoso AAS, Santos JZL, Tucci CAD, Silva CH Jr, Venturin N. Respostas nutricionais de mudas de sumaúma à adubação nitrogenada, fosfatada e potássica. Científica (Jaboticabal) 2016; 44(3): 421-430. http://dx.doi.org/10.15361/19845529.2016v44n3p421-430.

Carnevali NHS, Marchetti ME, Vieira MC, Carnevali TO, Ramos DD. Eficiência nutricional de mudas de Stryphnodendron polyphyllum em função de nitrogênio e fósforo. Ciência Florestal 2016; 26(2): 449-461. http:// dx.doi.org/10.5902/1980509822746.

Coimbra EC, Vazquez GH, Nogueira TO. Superação de dormência e o uso de fungicida em diásporos de teca. Revista Brasileira de Engenharia Agrícola e Ambiental 2014; 18(12): 1281-1286. http://dx.doi.org/10.1590/1807-1929/ agriambi.v18n12p1281-1286.

Dias IM, Barreto IDC, Ferreira RA. Efeito de diferentes recipientes e dosagens de fertilizante fosfatado no crescimento de espécies florestais nativas. Revista Interdisciplinar de Pesquisa e Inovação 2015; 1(1): 1-10.

Draper NR, Smith HA. Aplplied regression analysis. 3rd ed. New York: Jonh Wiley; 1998. http://dx.doi. org/10.1002/9781118625590.

Empresa Brasileira de Pesquisa Agropecuária - EMBRAPA. Serviço Nacional de Levantamento e Conservação de Solos. Manual de métodos de análise do solo. 2. ed. Rio de Janeiro: Embrapa; 1997. 212 p.

Favare LG, Guerrini IA, Backes C. Níveis crescentes de saturação por bases e desenvolvimento inicial de teca em um Latossolo de textura média. Ciência Florestal 2012; 22(4): 693-702. http://dx.doi.org/10.5902/198050987551.

Gomes JM, Paiva HN. Viveiros florestais: propagação sexuada. Viçosa: UFV; 2006. 116 p.

Gonçalves EO, Paiva HN, Neves JCL, Gomes JM. Nutrição de mudas de angico-vermelho (Anadenanthera macrocarpa (Benth.) Brenan) submetidas a doses de N, P, K, Ca e Mg. Revista Árvore 2012; 36(2): 219-228. http://dx.doi. org/10.1590/S0100-67622012000200003.

Gonçalves EO, Paiva HN, Neves JCL, Klippel VH, Caldeira MVW. Crescimento de jacarandá-da-bahia (Dalbergia nigra ((Vell.) Fr. All. ex Benth)) sob diferentes doses de NPK. Cerne 2014; 20(3): 493-500. http://dx.doi.org/10.1590/01 047760201420031220 .

Hair JF Jr, Anderson RE, Tatham RL, Black WC. Análise multivariada de dados. Porto Alegre: Bookman; 2005. 593 p.

Hair JF Jr, Black WC, Babin BJ, Anderson RE, Tatham RL. Análise multivariada de dados. Porto Alegre: Bookman; 2009. 688 p.

Indústria Brasileira de Árvores - IBÁ. Anuário Estatístico IBÁ 2016. Brasília: IBÁ; 2016. 96 p.

Inocêncio MF, Carvalho JG. Características morfológicas e absorção de nutrientes em duas espécies florestais sob diferentes soluções nutritivas. Global Science Technology 2013; 6(3): 124-136. http://dx.doi.org/10.14688/1984-3801. v06n03a13.
Johnson RA, Wichern DW. Applied multivariate statistical analysis. 6th ed. New Jersey: Prentice Hall; 2007.

Khattree R, Naik DN. Multivariate data reduction and discrimination with SAS software. Cary: SAS Institute Inc.; $2000.558 \mathrm{p}$

Kutner MH, Nachtsheim CJ, Neter J. Applied linear regression models. 4th ed. New York: McGraw-Hill Irwin; 2004.

Lange A, Silva JG Jr, Caione G. Substratos para produção de mudas de Schizolobium amazonicum. Tecnologia e Ciência Agropecuária 2014; 8(1): 49-54.

Locatelli M, Vieira AH, Macedo RS, Pequeno PLL. Caracterização de sintomas de deficiências em mudas de teca (Tectona grandis L.f.). Rondônia: Embrapa Rondônia; 2006. 4 p. (Circular Técnica, no. 90).

Malavolta E, Vitti GC, Oliveira SA. Avaliação do estado nutricional das plantas: princípios e aplicações. 2. ed. Piracicaba: POTAFOS; 1997. 319 p.

Malavolta E. Elementos de nutrição mineral de plantas. São Paulo: Agronômica Ceres; 1980. 251 p

Menegatti RD, Navroski MC, Guollo K, Fior CS, Souza AG, Possenti JC. Formação de mudas de guatambu em substrato com hidrogel e fertilizante de liberação controlada. Revista Espacios 2017; 38(22): 35-47.

Mingoti SA. Análise de dados através de métodos de estatística multivariada: uma abordagem aplicada. Belo Horizonte: Editora UFMG; 2005

Protásio TP, Trugilho PF, Neves TA, Vieira CMM. Análise de correlação canônica entre características da madeira e do carvão vegetal de Eucalyptus. Scientia Forestalis 2012; 40(95): 317-326.

R Development Core Team. R: a language and environment for statistical computing. Vienna: R Foundation for Statistical Computing; 2014.

Souza NH, Marchetti ME, Carnevali TO, Ramos DD, Scalon SPQ, Silva EF. Estudo nutricional da canafístula (II): eficiência nutricional em função da adubação com nitrogênio e fósforo. Revista Árvore 2012; 36(5): 803-812. http://dx.doi.org/10.1590/S0100-67622012000500002.

Stahl J, Ernani PR, Gatiboni LC, Chaves DM, Neves CU. Produção de massa seca e eficiência nutricional de clones de Eucalyptus dunnii e Eucalyptus benthamii em função da adição de doses de fósforo ao solo. Ciência Florestal 2013; 23(2): 287-295. http://dx.doi.org/10.5902/198050989275.

Trazzi PA, Caldeira MVW, Cusatis AC, Higa AR. Crescimento e nutrição de mudas de Tectona grandis produzidas em substratos orgânicos. Scientia Forestalis 2014; 42(101): 49-56.

Trugilho PF, Lima JT, Mori FA. Correlação canônica das características químicas e físicas da madeira de clones de Eucalyptus grandis e Eucalyptus saligna. Cerne 2003; 9(1): 66-80.

Valeri SV, Corradini L. Fertilização em viveiro para produção de mudas de Eucaliptus e Pinus. In: Gonçalves JLM, Benedetti V, editor. Nutrição e fertilização florestal. Piracicaba: IPEF; 2000. p. 168-190. 